\title{
4 Challenging Patriarchy: Marriage and the Reform of Marriage Law in Imperial Germany and the Weimar Republic
}

"If it were not for husband and wife," the German social historian and writer Wilhelm Heinrich Riehl (1823-1897) wrote in 1855, “one could think people on earth [are] destined for freedom and equality. However, because God created women and men, he made inequality and dependence basic elements of all human development." ${ }^{1}$ Gender according to Riehl not only constituted ideas of inequality and domination but contributed significantly to the construction of humanity, to the construction of the modern state. Gender was, he argues, not only one of the most powerful producers of inequality, but the most powerful. This meant that the existence of the traditional family was defended just as much as the traditional position of women, indeed that the subordination of women in marriage was regarded as a paradigm of human inequality and subordination par excellence. As a consequence, the exclusion of married women from the state necessarily resulted from their subordination in the family. The patriarchally organized family thus was not only a mirror image but also a basic element of the state.

No wonder that women within the context of the Enlightenment started to question why all humans, including women, were not equal and why not in the family. "Wife, marriage and love exhibit the brand of slavery," expressed the feminist and philosopher Louise Dittmar (1807-1884) in 1849. "The man is master over his wife, the absolute monarch with unlimited power to give orders in his realm, and not even lip-service is paid to constitutional guarantees that may be applied to wives,"2 argued Hedwig Dohm (1831-1919) almost forty

1 Wilhelm Heinrich Riehl, Die Naturgeschichte des Volkes als Grundlage einer deutschen SocialPolitik: Die Familie, vol. 3 (Stuttgart/Augsburg: Cotta, 1855), 3.

2 Louise Dittmar, "Das Wesen der Ehe," in Das Wesen der Ehe nebst einigen Aufsätzen über die soziale Reform der Frauen, ed. Louise Dittmar (Leipzig: Verlag von Otto Wiegand, 1849), 51; Louise Dittmar, "Die männliche Bevormundung," in Das Wesen der Ehe nebst einigen Aufsätzen über die soziale Reform der Frauen, ed. Louise Dittmar (Leipzig: Verlag von Otto Wiegand, 1849), 15; Renate Möhrmann, Die andere Frau: Emanzipationsansätze deutscher Schriftstellerinnen im Vorfeld der Achtundvierziger-Revolution (Stuttgart: Metzler, 1977); Renate Möhrmann, ed., Frauenemanzipation im deutschen Vormärz: Texte und Dokumente (Stuttgart: Reclam, 1980); Gilla Dölle, ed., Eine “ächt weibliche Emancipation": Die Diskussion der Geschlechterbeziehungen um 1848 (Kassel: Archiv der deutschen Frauenbewegung, 1998); Marion Freund, "Mag der Thron in Flammen glühn!” Schriftstellerinnen und die Revolution 1848/49 (Königstein/Taunus: Helmer,

Ә OpenAccess. (C) 2021 Marion Röwekamp, published by De Gruyter. (cc) BY-NC-ND This work is licensed under the Creative Commons Attribution-NonCommercial-NoDerivatives 4.0 International License. 
years later for the necessity of suffrage for women as a tool to end the subordinate position of women in law in general, but especially within marriage. ${ }^{3}$ Women's first experiences with the law were often encounters of injustice such as the one Dittmar and Dohm formulated in the revolution of 1848 and in the restoration years, which saw the emergence of a tender and loosely organized women's movement in Germany. "It is not inappropriate and unfeminine to have knowledge of the sad and unworthy situation of one's own sex and to rebel against it, but it is inhuman and a disgrace to close your eyes and ears in cowardly egoism and to keep these worst things quiet," argued Marie Stritt (1855-1928) around the turn of the century. "The women ... demand more, they finally demand the recognition of their human rights and their human dignity-they demand justice!"4 The idea of equal rights for all humans, as expressed here by Marie Stritt and previously especially by Hedwig Dohm, embraced for the first time also humans of the female sex who, by law, had not been treated as subjects or citizens in their own right (but very much so in terms of obligations).

Not accidentally, parallel to raising their voices, women were immediately silenced after 1848. Women were not allowed to organize themselves in political organizations or edit newspapers and journals. The claim for female suffrage within the politically suffocating atmosphere of Imperial Germany was unthinkable, thus the women's movements focused first on the mothers, these demands seemed at first sight to be relatively harmless. ${ }^{5}$ Similarly, as it had been proven that educated mothers could better perform educational tasks, it could be shown that it was now only natural, as feminist Louise Otto-Peters (1819-1895) put it, "to inquire about the laws that affect these living conditions, to inquire what duties women, who marry, take on, what rights or protection the laws grant, recognize or deny them." ${ }^{\prime 6}$ Women claimed they were just trying to improve their legal

2004); Birgit Mikus, The Political Woman in Print: German Woman's Writing 1845-1919 (Oxford et al: Peter Lang, 2014).

3 Hedwig Dohm, Der Frauen Natur und Recht (Berlin: Wedekind \& Schwieger, 1876), 141-142. 4 Marie Stritt, Frauen-Landsturm: Flugblatt zum Familienrecht im bürgerlichen Gesetzbuch (Berlin: n.p., 1896), reprinted in Die Rechtsstellung der Frau im 1900: Eine kommentierte Quellensammlung, eds. Stephan Meder, Arne Duncker and Andrea Czelk (Cologne: Böhlau, 2010), 809, emphasis in the original.

5 Dittmar, "Das Wesen der Ehe," 47-75; Helene Lange, “Über das Frauenwahlrecht,” Neue Bahnen 33, no. 7 (1898): 68-69.

6 Louise Otto-Peters, Einige deutsche Gesetzes-Paragraphen über die Stellung der Frau, ed. Archiv der deutschen Frauenbewegung (ADF), NL-K-08 Deutscher Staatsbürgerinnenverband, Nachlass Louise Otto-Peters, 3; Marion Röwekamp, “Olympe de Gouges, Louise Otto-Peters und der Kampf um das Familienrecht in Frankreich und Deutschland," in Die Rechte der Frauen 1791-1866-2016, eds. Sandra Berndt and Gerlinde Kämmerer (Markkleeberg: Sax-Verlag Beu- 
position within the realm they worked in according to their "natural" roles in the interest of the family and the state. ${ }^{7}$ The idea of equal rights in a more extended way they stressed less in order not to raise hackles. But, almost unnoticed, these demands meant much more; they were the demand for the granting of full legal capacity to married women and thus the basis for full legal capacity for all women. The fight for equal rights in family law thus meant, on the one hand, the demand for equality under private law as a first step on the road to political equality and to break one of the locks that held them down legally, but also, at the same time, the more or less hidden fight for the right to vote for women, years before the women's movement was “open” about it. Indeed, until the 20th century, suffrage law and family law were closely linked because the exclusion of women from both rights was the starting point for their discrimination throughout the law. They conditioned each other in a form of deadlock or double bind, as historian Gisela Bock has called it. ${ }^{8}$ It was hard to escape discrimination within the family without gaining suffrage, and it was logically impossible to gain suffrage without gaining full legal capacity in private law (even though it later happened exactly like that).

While initially not successful, the idea of equal rights for women was in the world. It was not only in Germany that women claimed equal rights in the family. In fact, it was one of the major topics for international feminism during the last decades of the 19th and the first decades of the 20th century. ${ }^{9}$ All Western legal

cha, 2017), 21-43; Susanne Schötz, “'Einige Deutsche Gesetzes-Paragraphen' - Louise Otto-Peters und das Engagement des Allgemeinen Deutschen Frauenvereins für Frauenrechte," in Menschenrechte sind auch Frauenrechte, eds. Ilse Nagelschmidt et al. (Leipzig: Leipziger Universitätsverlag, 2002), 53-78.

7 Marie Stritt, “Die Ehefrau und das bürgerliche Gesetzbuch," in Die Rechtsstellung der Frau im 1900: Eine kommentierte Quellensammlung, eds. Stephan Meder, Arne Duncker and Andrea Czelk (Cologne: Böhlau, 2010), 812.

8 Gisela Bock, "Frauenwahlrecht. Deutschland um 1900 in vergleichender Perspektive," in Geschichte und Emanzipation: Festschrift für Reinhard Rürup, eds. Michael Grüttner et al. (Frankfurt am Main/New York: Campus, 1999), 119; Marion Röwekamp, “The Double Bind: Von den Interdependenzen des Frauenwahlrechts und des Familienrechts vor und nach 1918," in 100 Jahre Frauenwahlrecht: Kampf, Kontext, Wirkung, eds. Hedwig Richter and Kerstin Wolff (Hamburg: Verlag des Hamburger Instituts für Sozialforschung, 2018), 99-121.

9 Karen Offen, "National or International? How and Why the Napoleonic Code Drove Married Women's Legal Rights onto the Agenda of the International Council of Women and the League of Nations: An Overview," in Family Law in Early Women's Rights Debates, eds. Stephan Meder and Christoph-Eric Mecke (Cologne: Böhlau, 2013), 42-59; Sara Kimble and Marion Röwekamp, "Legal Cultures and Communities of Female Protest in Modern European History, 1860 -1960s," in New Perspectives on European Women's Legal History, eds. Sara Kimble and Marion Röwekamp (New York: Routledge, 2017), 1-24; Marion Röwekamp, "Reform Claims in Family Law 
cultures permeated a patriarchal foundation of civil law and legalized the subordination of married women. Though the legal cultures and means were different in each country, women found themselves in a common struggle. ${ }^{10}$ At first the fight did not lead to results. This changed not only in Germany in the aftermath of World War I, emerged and prevailing ideas about democracy as well as with the ideas of the League of Nations to facilitate not only global peace but also the protection of the human rights of minorities, among them increasingly also women. Progressive forces in German society had by now adopted the idea that women deserved something called “equality.” In fact, women's equality was an intrinsic part of the idea of democracy. Accordingly, suffrage rights were granted almost immediately by the new Social Democrat government in 1918. "Germany has the honor to be the first republic founded on true principles of democracy, universal and equal suffrage for all citizens and all men and women," marveled Marie Stritt happily. ${ }^{11}$

There was a wide variety of ideas about what equality might mean in practice beyond enfranchisement. The period of the Weimar Republic in Germany was, as in most other European countries, a time of negotiation about the extent of women's citizenship rights. There was mostly an agreement that women should have suffrage rights, but further rights than suffrage needed to be bargained within the context of their specifically gendered place in society. Society felt that the extent of their citizenship rights should be defined by women's supposed nature and be based on their distinct roles as mothers and wives. These ideas were generally shared by women and men alike, even by large parts of the women's movements; they just argued that women's nature was different but equally important for society and that it would "heal" the existing problems of the state that were caused by women not participating. But many women also believed that equality should, in principle, not be determined by gender and thus that women and men should be treated equally in terms of the law. This, however, was also claimed by women who thought women were different by na-

and Legal Struggles within the International Council of Women, 1888-1914,” in Forging Bonds Across Borders: Transatlantic Collaborations for Women's Rights and Social Justice in the Long Nineteenth Century, eds. Anja Schüler and Britta Waldschmidt-Nelson (Washington, DC: Bulletin of the German Historical Institute, Supplement 13, 2017), 75-93.

10 Meder and Mecke, Family Law; Stephan Meder and Christoph-Eric Mecke, eds., Reformforderungen zum Familienrecht International, vol. 1: Westeuropa und die USA (1830-1914) (Cologne: Böhlau 2015); Kimble and Röwekamp, "Legal Cultures," 1-43.

11 Marie Stritt, “Germany: Victory for Woman Suffrage,” International Women’s News 13, no. 4 (1919): 44-48. 
ture. The difference should not emphasize their exclusion from enjoying equal rights with men but justify it.

These demands were raised in many different legal areas of the interwar years: in criminal law, in the access to all professions plus civil service, but especially in family law. But as women were felt to have their natural vocation and space within the family, the claim for equality within the family was the punchline for equality claims. It was one thing for some women to be parliamentarians or to work in small numbers in male-dominated professions, but women being equal within the family was a totally different matter. Here, the entire setup of society and thus a nerve of society was touched. This claim was the most threatening one women raised within the years of the Weimar Republic, and the strongest fight for or against reform emerged as a consequence. Here, the limits of the negotiation over how much equality Germany's first democracy was to bring to women ended clearly for the majority of society.

The timeframe of this chapter will cover the beginning of the debates about marriage across two attempts by the women's movement to change family law. The process of becoming aware of injustice led gradually, helped by the organization also on an international level, to an understanding that women should be treated equally by the law, especially in the family, and should be citizens with equal citizenship laws to men. I will analyze this discourse within the time of Imperial Germany and the Weimar Republic, showing how the process of negotiating an equal position for women in German society and in the family unfolded over time. While women started to claim this from early on, within the stifling context of the monarchy, men tended to ignore their plights completely. This changed in Germany's first democracy. The chapter shows how the limits of equality and of the rights guaranteed in the constitution were reached as far as changes as rights in the family were concerned. And, thus, how democracy failed in one of the areas usually not assumed to be connected to be a pillar of democracy: full equal rights for all female citizens.

\section{Re-Enforcing Patriarchy: Marriage and the Family in Imperial Germany}

The far-reaching changes in the social and economic foundations of society, which began at the end of the 18th century, especially with the increasing industrialization of the second half of the 19th century, did not remain without effects on the family constitution and form the background of the intellectual-historical development to be described in the following. Of central importance in the pre- 
sent context is the separation of domestic and professional spheres, which characterized the new family forms and enforced the separation of different roles for men and women. The felt dissolution of life and state as well of the family into single units supported by the growing ideas of emancipation of women were interpreted as threatening the entire life of the state and had to be counteracted. German political and legal doctrine thus set out in search of a new basis that could secure supra-individual validity and duration for the family. They invented the "traditional family" by trying to adjust to the reality of the modern state on the one hand but, on the other, by incorporating ideas of the natural subordination of women. "12 "The home is still the articulation of the existing union, the organizational foundation of the social body, the strong pillar of the moral and economic order," wrote the lawyer Otto von Gierke (1841-1921), reflecting ideas of not only the legal profession but broad parts of society that were reflected within the new German civil law. ${ }^{13}$

The German Civil Code (Bürgerliches Gesetzbuch, BGB), which came into effect in 1900, was one of the last civil laws codified within Europe following the founding of Germany as a nation in $1871 .^{14}$ Its idea was to bring an equal law to all citizens of formerly 39 different territories. Partly it was also a reaction to the imposition of French law on German land, as parts of the empire were still ruled by the French Civil Code. It was also a vital part of the political ideas and project of German liberals to dismantle the old feudal society (Ständegesellschaft), to secure the separation of church and state, and, besides all that, to achieve national unity and contribute to the strength of the nation-state. As such, the BGB was, besides a legal project, also a social, highly political, and cultural project. This is especially obvious also in the family law which embodied the interests and values that were able to prevail in the German Empire at the end of the 19th century. It reflected the changes to which the position of the family was subject over the course of the century. Here, it did not reflect the real position of women, as was often criticized, but was intended to protect a model of the family

12 Ursula Vogel, “Is Citizenship Gender-Specific?” in The Frontiers of Citizenship, eds. Ursula Vogel and Michael Moran (New York: St. Martin’s Press, 1991), 66-67.

13 Otto von Gierke, Der Entwurf eines bourgeoisen Gesetzbuchs und das deutsche Recht (Leipzig: Dunker \& Humblot, 1899), 34.

14 For the situation of women in law before 1900, see Barbara Dölemeyer, "Frau und Familie im Privatrecht des 19. Jahrhunderts," in Frauen in der Geschichte des Rechts: Von der frühen Neuzeit bis zur Gegenwart, ed. Ute Gerhard (Munich: C.H. Beck, 1997), 633-658; Ute Gerhard, Gleichheit ohne Angleichung: Frauen im Recht (Munich: C.H. Beck, 1990); Ute Gerhard, "Legal Particularism and the Complexity of Women's Rights in Nineteenth Century Germany," in Private Law and Social Inequality in the Industrial Age: Comparing Legal Cultures in Britain, France, Germany, and the United States, ed. Willibald Steinmetz (Oxford: Oxford University Press, 2000), 137-154. 
that had never existed in this form; the "traditional nuclear family" was re-invented on the basis of old ideas of women's subordination in the family to preserve the patriarchy within the family. Designed to support and reinforce the power of men, marriage and the family acquired a more and more public character. $^{15}$

Beyond its modern outlook in terms of legal formality and methodology as well as of granting women some rights such as legal capacity and parental power, in its content, the BGB tightened the legal situation of women and notably gave men the power over all her property besides making them the sole decision-making authority in the house. It was set up so that the head of the conjugal community continued to be the husband, he was entitled to decide on all matters concerning the conjugal life, and he determined in particular the place of residence and domicile and had the last word in the marriage. The husband was obliged to support his wife, and she was obliged to manage the household and to cooperate. The reason given for this order in marriage was that it was the "natural order of the relationship."16

In terms of property law, it disenfranchised women fully. By stating that they wanted to clean up the complicated property regimes, of which there were more than 100 the German states, the BGB rationalized the pre-existing ideas and reinforced male patriarchy. In the final version, the man was granted his own right of administration and would appear in his own name "as head of the family." In addition, women could seldom file a case without the consent of the husband. So even if the husband mismanaged the property of the wife, she had no legal means to protect it.

The BGB formally introduced parental power over children, but then legislated that the "father has, by virtue of his parental power, the right and duty to take care of his child's person and property” ( $\$ 1627$ BGB). And, also with regard to the kids, the father had the last word in terms of decisions. Only in the event of the father's death did parental authority transfer to the mother. In the end, mothers were as lawless as before; they had obligations toward their children but no new rights besides formally receiving parental guardianship. Furthermore, the proposed law removed the rights of illegitimate children to make material or familial claims to their fathers.

15 Margaret Barber Crosby, "The Civil Code and the Transformation of German Society: The Politics of Gender Inequality, 1814-1919” (PhD diss., Brown University, 2001), 226-251.

16 Benno Mugdan, Die gesammten Materialien zum Bürgerlichen Gesetzbuch für das Deutsche Reich, vol. 4 (Berlin: G. Schenck, 1899), 59. 
Finally, the BGB tightened the divorce law as compared to the ARL. ${ }^{17}$ Divorce was only possible in cases of adultery and other exceptions and rested on the guilt principle. In divorce cases, if the woman was declared the guilty party, she would take her maiden name in order for status to be taken from her, and she would not receive alimony. Declarations of guilt affected custody, too.

In reality, all claimed legal progress was solely paper rights to women. It was a cross-influence of all norms that only made clear how much women were disenfranchised. Besides formal differences, the laws concerning marriage and family mirrored those of other earlier European civil codes such as the Napoleonic Code, the Austrian Civil Code of 1811, and the Prussian Civil Code of 1794. As a result, the maintenance of the existing order of marriage was placed above the individual interests of the wife-the content of the traditional family law was preserved in new legal forms. As far as the effect of the BGB is concerned, it seems to be true that it hardly differed from the marriage law of the "Sachsenspiegel"; marriage law has remained almost static over a period of at least one thousand years. The BGB again designated women as second-class citizens in private law. ${ }^{18}$

\section{Culture of Protest: Women's Reaction against the BGB}

Thus, the women's movement had, almost right from the moment of its institutional founding, begun to challenge a wife's legal subordination to her husband. In fact, it was the process of the codification of the BGB which led in the German women's movement to an early awareness of the role of law for the discrimination of women in general and in the family in particular. ${ }^{19}$ Realizing that women

17 Hannelore Schröder, Die Rechtlosigkeit der Frau im Rechtsstaat: Dargestellt am Allgemeinen Preußischen Landrecht, am Bürgerlichen Gesetzbuch und an J.G. Fichtes Grundlage des Naturrechts (Frankfurt am Main/New York: Campus, 1979); Marianne Weber, Ehefrau und Mutter in der Rechtsentwicklung: Eine Einführung (Tübingen: J. C .B. Mohr, 1907), 331-341; Susanne Weber-Will, Die rechtliche Stellung der Frau im Privatrecht des Preußischen Allgemeinen Landrechts von 1794 (Frankfurt am Main/New York: Peter Lang, 1983), 281-286.

18 Ute Rosenbusch, Der Weg zum Frauenwahlrecht in Deutschland (Baden-Baden: Nomos, 1998), 275.

19 Christiane Berneike, Die Frauenfrage ist Rechtsfrage: Die Juristinnen der deutschen Frauenbewegung und das Bürgerliche Gesetzbuch (Baden-Baden: Nomos, 1995); Orla-Maria Fels, "Die Deutsche Bürgerliche Frauenbewegung als juristisches Phänomen” (PhD diss., Freiburg University, 1959); Sabine Klemm, Frauenbewegung und Familienrecht 1848 bis 1933: Eine Betrachtung 
were mostly lawless within the area that was supposedly the center of their life, the family, the newly founded General German Women's Club (Allgemeiner Deutscher Frauenverein, ADF) focused more and more on the law of the family from 1869. The situation was dire as women rightly feared that within the context of the codification process of the German Civil Code, the new law would repeat or even tighten the subordination of women in the family. Louise Otto-Peters collected the complaints and the demands of women as far as their situation in the family was concerned. Based on this material, she published a memorandum in 1876 on the legal situation of women in the family and warned women about the legal consequences a marriage had for them..$^{20}$ One year later, a commission of the ADF worked out the first legal demands of women, which turned out to be one of the first petitions of women to the Reichstag, signed by around $10,000-12,000$ women. ${ }^{21}$ This was the genesis of the first mass-organized movements of German women and the beginning of debates over marriage law, debates which would keep going well into the 21st century.

In the petition, they requested the removal of provisions that deemed women "incapable," modifications to divorce law, and changes to custody rights for both parents. In addition, they asked that women be allowed control over their own property and inheritance. They requested the removal of patriarchal authority and custody over children in the event of divorce and the elimination of "general stylistic elements in the law" that reduced women to the same status as minorities and invalids.

When the publication of the first draft of the BGB was published in 1888, this brought heavy disappointment as none of their claims had been considered. But when the second committee came together in 1890 and the women could observe the way the public debate was turning against their claims, a new wave of more

anhand von Quellen (Tübingen: Campus, 1999); Stephan Meder, Arne Duncker, and Andrea Czelk, eds., Die Rechtsstellung der Frau um 1900: Eine kommentierte Quellensammlung (Cologne: Böhlau, 2010); Stephan Meder, Arne Duncker, and Andrea Czelk, eds., Frauenrecht und Rechtsgeschichte: Die Rechtskämpfe der deutschen Frauenbewegung (Cologne: Böhlau, 2006); Tanja-Carina Riedel, Gleiches Recht für Mann und Frau: Die bürgerliche Frauenbewegung und die Entstehung des BGB (Cologne: Böhlau, 2008); Schröder, Die Rechtlosigkeit; Weber, Ehefrau und Mutter, 407-505.

20 AddF, NL Louise Otto-Peters aus Bestand NL-K-08, 6-7/2. Louise Otto-Peters, Einige deutsche Gesetzes-Paragraphen über die Stellung der Frau, ed. ADF, aus: Schötz, "Einige Deutsche Gesetzes-Paragraphen,” 53-78; Röwekamp, “Olympe de Gouges,” 21-43.

21 "Petition of the Allgemeinen Deutschen Frauenverein to the Reichstag," Neue Bahnen 12, no. 8 (1877): 57-59, printed in Meder et al., Rechtsstellung der Frau, 36-41. 
serious protests emerged. ${ }^{22}$ This time it was helped by the founding of the German branch of the International Council of Women, the Bund Deutscher Frauenvereine (BDF), in 1894. The BDF and ADF together pooled all their efforts into fighting the BGB. In fact, for the first time, women formulated that the legal question was at the center of the so-called woman's question. The Swiss-educated Anita Augspurg (1857-1943), one of the first German female lawyers, phrased that the women's question was to a considerable degree a question of economics, but first and foremost a legal question. ${ }^{23}$ The BDF formed a legal committee and published several pamphlets, while a number of petitions were written and launched at different sessions of parliament and the drafting committee of the BGB. ${ }^{24}$ In the same year, the first organized strike of female workers occurred as a protest against the Civil Code and was joined by 500 middle-class women. ${ }^{25}$

But women's protests were to no avail. Other protests against the BGB came from the Socialist Party as well as the Center Party and Catholics. The latter in general opposed the new law because, in their view, the state interfered too much within the sphere of the church; marriage was understood as a holy sacrament and not as a matter of the worldly state. Since the mandatory introduction of civil marriages in 1875, the matter of marriage law and the focus on the family became the focus and defining issue the Catholics turned around. For them, every change meant an attack on their identity. This trauma was still alive in the interwar years, though Catholics in general started to feel more "German"

22 Riedel, Gleiches Recht für Frau und Mann; Meder et al., Frauenrecht und Rechtsgeschichte; Berneike, Die Frauenfrage ist Rechtsfrage.

23 Anita Augspurg, “Gebt acht, solange noch Zeit ist!” Die Frauenbewegung 1, no. 1 (1895): 4-5, printed in Meder et al., Rechtsstellung der Frau, 41-42.

24 For example: Auguste Schmidt and Henriette Goldschmidt, Petition und Begleitschrift betreffend das "Familienrecht" in dem Entwurf des neuen bürgerlichen Gesetzbuches für das Deutsche Reich (Leipzig: Schäfer, 1896); Olga von Beschwitz, Begleitschrift zu der Petition des Bundes Deutscher Frauenvereine an den Reichstag betr. das Familienrecht des neuen BGB für das Deutsche Reich (Frankenberg: L. Reisel, 1899); Cäcilie Dose and Alma Kriesche, Die Stellung der Frau und Mutter im Familienrecht der ausserdeutschen Staaten und nach den Bestimmungen des neuen bürgerlichen Gesetzbuches für das Deutsche Reich (Frankenberg: L. Reisel, 1900).

25 On socialist women, see Beatrix Geisel, Klasse, Geschlecht und Recht: Vergleichende sozialhistorische. Untersuchung der Rechtsberatungspraxis von Frauen- und Arbeiterbewegung (18941933) (Baden-Baden: Nomos, 1997), 102-105; Joseph Joos, Die sozialdemokratische Frauenbewegung in Deutschland (Mönchen-Gladbach: Volksvereins-Verlag, 1912); Heinz Niggemann, Emanzipation zwischen Sozialismus und Feminismus: Die sozialdemokratische Frauenbewegung im Kaiserreich (Wuppertal: Hammer, 1981); Hanna Szymanski, Theorie und Lebenswirklichkeit: Ehe und Eherechte im Spiegel sozialdemokratischer Forderungen im deutschen Kaiserreich (Köln: Böhlau, 2013). 
than only Catholic. ${ }^{26}$ For the socialists, it was the other way around. They claimed the same as the women's movement. ${ }^{27}$ Without considering the broad protests of different groups of society, the law was approved in August 1896 and came into effect on 1 January 1900.

With the introduction of the BGB, gender relations were reinforced and redefined in such a way that it reflected its entrance into daily life as positive law. But it also symbolized a growing civil society that was unequal from the core; the reform of the law was not only demanded by the women's movement but by broader parts of society such as socialists and others who saw changes as basic democratic rights. As Anita Augspurg argued, the BGB had imposed new political duties on women but denied them every political right. ${ }^{28}$ The civil code made it obvious to women that they were not considered citizens.

\section{Negotiating Equality: The Constitution and Women's Equality in the Family in the Weimar Republic}

However, when Germany was defeated in World War I and in the wake of the November Revolution in 1918, women could at last see a potential for equal rights within a democratic republic. Women's suffrage became an almost overnight reality to the great surprise of the BDF, socialist women, and other women's organizations who had fought for this right for decades and who celebrated it as a major victory. That women's equality involved political rights was soon generally agreed on, even by those who had been opposed to women voting and participating in politics such as the conservative parties, who rapidly began to rely heavily on their women's voters. But despite this acceptance of women's voting rights, there still remained the question of whether and how far their equality should extend outside of the arena of voting rights. The official narrative of granting women equality runs counter to the reality of the complex struggle of

26 Ellen Lovell Evans, The German Center Party, 1870-1933: A Study in Political Catholicism (Carbondale: Southern Illinois University Press, 1981); Michael B. Gross, The War Against Catholicism: Liberalism and the Anti-Catholic Imagination (Ann Arbor: University of Michigan, 2004). 27 Wolfgang Plat, "Die Stellung der deutschen Sozialdemokratie zum Grundsatz der Gleichberechtigung der Frau auf dem Gebiet des Familienrechts bei der Schaffung des Bürgerlichen Gesetzbuches des Deutschen Reiches” (PhD diss., Humboldt University Berlin, 1966); Szymanski, Theorie und Lebenswirklichkeit, $100-134$.

28 Augsburg, "Gebt acht," 4-5. 
women, who soon came to realize that the aftermath of suffrage meant a reinforced struggle for all the other equal rights that by no means came as a logical consequence of women's suffrage. Suffrage was the tool and leverage they needed to go on with the new struggles. The reform of family law was one of the evergrowing varieties of this struggle, probably at the center of it, as here women had to free themselves from the second "lock" that kept them in a state of legal discrimination in order to become citizens with full rights. ${ }^{29}$

In consequence of World War I, the number of women in comparison to men doubled. Many women who had been responsible heads for the household in war time were relieved to go back to their homes and duties as only wives and mothers, willing to embrace the idea of a domestic sphere for women and a public one for men as often represented in women's magazines and the popular press. ${ }^{30}$ But many women had also experienced the war time with the greater necessity for women to work a new independence and self-determination. Managing the families by themselves as heads of the household, besides often working to support them, had made them escape the domestic sphere in big numbers. For many women, even those who were not active in the women's movement, the opportunities created by the war shaped a will to keep on working and participating in the public sphere. Especially the younger ones without families were keen on keeping their independence from the war times. This independence at times went hand in hand with a loosening of sexual and moral codes. The embodiment of male fears was the so-called "new woman," single and childless, sexually emancipated with a "Bubikopf" (bob haircut), and into fashion, who symbolized the liberating changes in gender roles and raising the fears of the German nation that was about to falter with this egoism of women. Throughout the 1920s, many women, especially young women, rejected the exclusively domestic role in favor of gainful employment outside the home, economic independence, and the postponement of marriage because it suggested the end of freedom with its still patriarchal structure and traditional gender roles. Mass en-

29 Röwekamp, “The Double Bind,” 99-121; Marion Röwekamp, “"Männer und Frauen haben grundsätzlich die gleichen staatsbürgerlichen Rechte': Weimar - Meilenstein auf dem Weg zur Gleichberechtigung der Geschlechter?" in Die Weimarer Verfassung, Wert und Wirkung für die Demokratie, ed. Friedrich-Ebert-Stiftung (Erfurt: Friedrich-Ebert-Stiftung, 2009), 235-264; Dieter Schwab, "Gleichberechtigung und Familienrecht im 20. Jahrhundert," in Frauen in der Geschichte des Rechts: Von der Frühen Neuzeit bis zur Gegenwart, ed. Ute Gerhard (Munich: C.H. Beck, 1997), 790 - 827; Inge Schwanecke, "Die Gleichberechtigung der Frau unter der Weimarer Reichsverfassung” (PhD diss., University of Heidelberg, 1977).

30 Birthe Kundrus, Familienpolitik und Geschlechterverhältnisse im Ersten und Zweiten Weltkrieg (Hamburg: Christians, 1995), 124-141. 
tertainment, fashion, and leisure time reshaped unmarried women's lives. At the same time, Germany experienced a flood of marriages (Heiratsflut) but reduced the number of children in the family to a maximum of two. Marriage counseling, sexuality, birth control, abortion, eugenics, and racial hygiene characterized the public debate and reality of women. The family was seen as the key to society's health; it was just that the left and right drew different conclusions about how to improve the family. Society and women especially were torn between the idea of a new future with more freedom and the traditional family. In this way, they were, as historian Atina Grossman has phrased it, at once "modernity's agents, victims, and mediators." 31

Returning soldiers found their wives changed, and they in turn did not find the same men who had left; their situation had changed. Divorce rates as well as birth rates of illegitimate children were rising while marriage rates were sinking. ${ }^{32}$ But the possibility of granting divorce based on the BGB was still difficult; the most potent discontent that emerged with the family law and especially the divorce rules came from veterans and their wives. This all made the so-called "crisis of the family" obvious, yet calls for new socio-political measures were heard not only from the women's movement.

Mostly, it was demands for the better protection of mothers and children within the family that were made. This change of perspective was not due to the ideas of rights of equality in the sense of securing the rights of individuals notwithstanding their gender. Instead, the emphasis was on the preservation of family and state. Thus, in 1919, the family was for the first time placed under constitutional protection in the Weimar constitution. Welfare programs

31 Atina Grossman, Reforming Sex: The German Movement for Birth Control and Abortion Reform 1920-1950 (New York: Oxford University Press, 1995), 5. See also Julia Sneeringer, Winning Women's Votes: Propaganda and Politics in Weimar Germany (Chapel Hill: University of North Carolina Press, 2002), 12; Helen Boak, Women in the Weimar Republic (Manchester: Manchester University Press, 2015), 200 - 205; Cornelie Usborne, The Politics of the Body in Weimar Germany: Women's Reproductive Rights and Duties (Ann Arbor: University of Michigan Press, 1992), 84-85; Katharina von Ankum, ed., Women in the Metropolis: Gender and Modernity in Weimar Culture (Berkeley: University of California Press, 1997); Hanna Vollmer-Heitmann, Wir sind von Kopf bis Fuß auf Liebe eingestellt: Die zwanziger Jahre (Hamburg: Kabel, 1993); Michelle Mouton, From Nurturing the Nation to Purifying the Volk: Weimar and Nazi Family Policy, 1918-1945 (Cambridge/New York: Cambridge University Press, 2007).

32 Ida Rost, Die Ehescheidungen der Jahre 1920-1924 von in Sachsen geschlossenen Ehen, unter besonderer Berücksichtigung der Dauer der Ehen und des Heiratsalters der geschiedenen Ehegatten (Leipzig: Vieweg \& Teubner, 1927); Dirk Blasius, Ehescheidung in Deutschland (1794-1945) (Göttingen: Vandenhoeck \& Ruprecht 1987), 155-187; Karen Hagemann, Frauenalltag und Männerpolitik: Alltagsleben und gesellschaftiches Handeln von Arbeiterfrauen in der Weimarer Republik (Bonn: Dietz, 1990), 179-185. 
for mothers, children, babies, and youth were the beginning not only of the welfare state but also of state-regulated family policy. ${ }^{33}$

This understanding of the family clashed with the claims for equal rights of women, which were also reinforced after the war and placed under constitutional protection. The Constitution itself was not clear in its priority in terms of how it suggested the protection of family and women's equality at the same time. Art. 119 protected the idea of the "traditional" family which needed to keep women within the home and subordinate to the husband, while at the same time it stated that men and women were equal in marriage. ${ }^{34}$ Art. 109 specified that "all Germans are equal before the law. Men and women have in principle the same civic rights and duties.” This was the first time that the principles of gender equality were embodied in the constitution.

The problems the new constitution posed for women had already become apparent during the negotiations over its content in the Constitutional Assembly. Female parliamentarians such as the socialists Marie Juchacz (1879-1956), Luise Zietz (1865 -1922), and Marie Baum (1874-1964) of the German Democratic Party (DDP) had quickly identified the problems in the draft of Hugo Preuss (18601925) and asked for changes. They wanted different wording for Art. 109 and suggested a broader equality clause, because "we want this constitution to state that this reform of civil law must be started immediately and that the provisions that disadvantage the legal position of women in this area must be removed." ${ }^{35}$ They wanted to make sure that a reform of the family law was enforced and claimed that the law as it was did not grant equal rights to all citizens and thus needed to be changed. Only by considering the rights of women fully, beyond only in prin-

33 Karin Hausen, “Arbeiterinnenschutz, Mutterschutz und gesetzliche Krankenversicherung im Deutschen Kaiserreich und in der Weimarer Republik: Zur Funktion von Arbeits- und Sozialrecht für die Normierung und Stabilisierung der Geschlechterverhältnisse," in Frauen in der Geschichte des Rechts, 759-771; Young-Sun Hong, Welfare, Modernity, and the Weimar State (Princeton, NY: Princeton University Press, 1998).

34 Heinrich Aldag, Die Gleichheit vor dem Gesetz in der Reichsverfassung: Eine öffentlichrechtliche Abhandlung auf rechtsvergleichender Grundlage (Berlin: Heymann, 1925); Alfred Wieruszowski, "Artikel 119: Ehe, Familie, Mutterschaft," in Die Grundrechte und Grundpflichten der Reichsverfassung, vol. 2: Artikel 118-142, ed. Hans Carl Nipperdey (Berlin: Hobbing, 1930), 72-94; Rebecca Heinemann, Familie zwischen Tradition und Emanzipation: Katholische und sozialdemokratische Familienkonzeptionen in der Weimarer Republik (Munich: Oldenbourg 2004), 67108.

35 Verhandlungen der verfassunggebenden Deutschen Nationalversammlung 328 (1919/20), 57. session July 15, 1919 (Berlin: Norddeutsche Buchdruckerei, 1920), MP Juchacz: 1560, MP Zietz: 1563-64, MP Quarck: 1565-66; see Heinemann, Familie zwischen Tradition und Emanzipation, 151-212; Heide-Marie Lauterer, Parliamentarierinnen in Deutschland 1918/19-1949 (Königstein, Taunus: Ulrike Helmer, 2002), 139-147. 
ciple, would the state be truly democratic. ${ }^{36}$ But their opponents notably rejected this idea; they wanted to keep the man as head of the household model and felt that a reform would threaten the concept of the family and, by extension, the state itself. Lawyer and DDP member of parliament Hermann Luppe (18741945) pointed out that the constitution never intended to grant women equal rights within the family. ${ }^{37}$

This group interpreted the principle of equality in a way that did not threaten the established order of gender relations, especially in the family, and did not want to challenge it. According to this interpretation, women should have equality but only within the context of their specifically historically gendered place in society, meaning, if at all, outside of the family. The reason for their extended citizenship would be not equality with men as such but be based on their distinct roles as wives and mothers and thereby limited. Consequently, their opponents could make sure that their new roles would not conflict with their place in the family and that they would remain subordinate to men. Accordingly, women were not seen as individual citizens but as members of a unit, which kept on mirroring the natural differences between men and women.

Independently from the two opinions about the direct extent of the constitutional law on the family law, factually both articles contained a limitation to this citizenship for women: Art. 109 only granted equality "in principle" and Art. 119 protected the family at the same time and thus immediately compromised the promised equality for women. In effect, the protection of the family meant that the law had the duty to treat its citizens as gendered beings and bestow rights upon them based on the roles they fulfilled as women and as men. Men would still be seen as the head of the household, and women still as being at home as mothers and wives. This implied a conflict with the formulation that granted women equal rights with men. It claimed equality while at the same time saying that the law should keep discriminating between them as far as the relationship within the family was concerned. So, the reality of gender difference was implanted within the constitution and gave way to further arguments against the abolishment of the privileges of sex that men had enjoyed for centuries and kept on enjoying. The writers of the constitution did not resolve this contradiction; the clashing formulation of the equality of men and women in the constitution in Arts. 109 and 119 was the compromise that could be achieved and, in consequence, the reason for a number of new struggles about the extent

36 Verhandlungen Nationalversammlung, 1565.

37 MP Luppe, ibid., 1561, 1567-1568; MP Teusch, ibid., 1560 -1561; MP Heinze, ibid., 1564; MP Quidde, ibid., 1566. 
of the concrete meaning of women's equality. It created a tension over how women should be seen in the state and the extent to which they were treated as active citizens or still as legal subjects to their husbands. Central among them was the question of the reform of family law.

\section{Attempts to Reform Family Law}

With women's suffrage, the conditions for political work for women changed dramatically. Prior to 1918, women's organizations had had to rely on addressing petitions to the German Reichstag and had no means of legal redress. Now, with the BDF being so much stronger, including in numbers-it now consisted of around half a million members and around 2,200 member organizations ${ }^{38}-$, women were able to use parliamentary tools such as committees in order to bring petitions, file their demands via a political party, or become parliamentarians themselves. Thus, they could participate directly in the political process and use the arguments of the new constitution to claim new rights. The two parties which favored their claims were the DDP and the Social Democratic Party (SPD), which often brought in the suggestions of the BDF as their own legal claims. The women's movement gained influence not only via the female parliamentarians who often were also members of the women's movement but also via male supporters whom they asked to work as go-betweens for them. But in many instances, all female parliamentarians came together, regardless of the pressure of their parties, to push through their claims such as in the areas of peace, social welfare, and in the admission of female lawyers to the profession..$^{39}$ The family law reform was not one of these areas; here, the female parliamentarians were far too divided by their different ideologies. Even among feminists, the different ideas about the family were so strong that neither the female parliamentarians nor the women in the BDF and other women's organizations could find common ground.

38 Klaus Hönig, Der Bund Deutscher Frauenvereine in der Weimarer Republik 1919-1933 (Frankfurt am Main: Hänsel-Höhenhausen, 1995), 14.

39 See, for example, Max Hachenburg, "Interfraktioneller Antrag der weiblichen Reichstagsabgeordneten auf Zulassung von Frauen zu den juristischen Prüfungen,” Deutsche Juristen Zeitung 26 (1921): 174; Marie-Elisabeth Lüders, “Interfraktionelle Frauenarbeit,” Die Frau 27, no. 5 (1920): $154-156$. 
This became especially obvious in the debate on divorce, which was at the center of the reform proposals. ${ }^{40}$ The BDF, led by the reform proposals of its female lawyers such as Margarete Berent (1887-1965) and Marie Munk (18851978), called for divorce on the grounds of irretrievable breakdown, ${ }^{41}$ without allocation of guilt, on the grounds of mutual consent and of dislike for each other. ${ }^{42}$ DDP member of parliament Marie-Elisabeth Lüders (1878-1966) led the fight for divorce reform together with the socialist women in the Reichstag, first raising the issue in January 1921, when she called for divorce to be made easier. She, her party, and the socialist women under the leadership of Antonie Pfülf (1877-1933) submitted petitions and drafts introducing their ideas of divorce reform. ${ }^{43}$ In 1928, Pfülf gave a major speech in the Reichstag in which she pointed

40 Hilde Lion, Zur Soziologie der Frauenbewegung: Die sozialistische und die katholische Frauenbewegung (Berlin: Herbig, 1926); Heinemann, Familie zwischen Tradition und Emanzipation, 151211; Marion Röwekamp, "Der Kampf um die Ehe: Der Katholischer Frauenbund und das Zentrum im Richtungsstreit um eine Reform des Ehescheidungsrechts," in Die Frauen und der politische Katholizismus, eds. Markus Raasch and Andreas Linsenmann (Mainz: Schöningh, 2018), 210 237; Blasius, Ehescheidung, 187-197; Michael Humphrey, Die Weimarer Reformdiskussion über das Ehescheidungsrecht und das Zerrüttungsprinzip: Eine Untersuchung über die Entwicklung des Ehescheidungsrechts in Deutschland von der Reformation bis zur Gegenwart unter Berücksichtigung rechtsvergleichender Aspekte (Göttingen: Cuvellier, 2006), 15-242; Marion Röwekamp, "Gedachte Grenzen. Ehescheidungsrechtsforderungen als Grenze innerhalb der Bürgerlichen Frauenbewegung, 1918-1933,” Ariadne 57 (2010): 14-21; Werner Schubert, Die Projekte der Weimarer Republik zur Reform des Nichtehelichen-, des Adoptions- und des Ehescheidungsrecht (Munich/Vienna/Zurich: Ferdinand Schöningh, 1986), 82-92.

41 Marion Röwekamp, Marie Munk: Rechtsanwältin - Richterin - Rechtsreformerin (Berlin: Hentrich \& Hentrich, 2014, Marion Röwekamp, "Margarete Berent und Marie Munk: Pionierinnen im Kampf um gleiche Rechte für Frauen," in Streitbare JuristInnen: Eine andere Tradition, vol. 2, eds. Tanja Hitzel-Cassangnes and Joachim Perels (Baden-Baden: Nomos, 2015), 73-108.

42 Margarete Berent and Marie Munk, Vorschläge zur Abänderung des Familienrechts und verwandter Gebiete, LAB Rep, 235-01 BDF, MF-Nr. 2765; Ella Bormann, "Die Gleichstellung der Geschlechter im deutschen Eherecht,” Sozialistische Monatshefte 27, no. 19 (1921): 1036-1045; Marie-Elisabeth Lüders, "Vorschläge zum Ehescheidungsrecht," Die Frau 35 (1928): 325-331; Marie Munk, Vorschläge zur Umgestaltung des Rechts auf Ehescheidung und der elterlichen Gewalt nebst Gesetzesentwurf (Berlin: Herbig, 1923); Antonie Pfülf, "Die Reform des Ehescheidungsrechts," Arbeiterwohlfahrt 3 (1928): 3-9; Antonie Pfülf, "Die Auflösung der alten Familie," in Jugendnot, eds. Gerhard Danziger et al. (Leipzig: Oldenburg, 1922), 26-30; Emmy RebsteinMetzger, "Scheidung schuldlos zerrütteter Ehen," Deutsche Juristen Zeitung 32, no. 10 (1927): 715-719; Elisabeth Röhl, "Ehereform,” Die Gleichheit 29, no. 14 (1919): 109-111; Sophie Schöfer, “Notwendige Änderungen der ehelichen Rechtsgrundlagen,” Die Neue Zeit 40, no. 1/10 (1921): $230-234$.

43 Marion Röwekamp, "Von der Klassenkämpferin zur Republikanerin. Sozialdemokratinnen in der Weimarer Republik," in Geschlecht und Klassenkampf: Die "Frauenfrage” aus deutscher und 
out the discrepancy between the constitution and civil law and masterfully traced the misogynistic figures of the BGB as well as touched on the strong consequences of the economic dependence of women on men. ${ }^{44}$

Even supporters of reform found themselves with the contradiction that they generally agreed with the model of the traditional family and the common belief that it was the moral foundation on which the family, the state, and even humanity rested. For family reform supporters, the fact that the family was a social institution justified the state's regulation of it. Especially because reform meant a separation of the Church's strong hold over the family, because it separated religious practice from legal practice, it was meant to be more reasonable, more equal, more modern, and more democratic. The reform of divorces in particular allowed, in their opinion, justice to be brought to broken marital relationships without punishing one party as being guilty for the breakup of the marriage and freeing both parties for a new life and, more importantly, securing newly functional families for the state. According to these ideas, only happy families were allowed to raise children to be stable and good citizens, and sometimes divorce was the means to free children from dysfunctional families. Both sides agreed strongly on the family as the social foundation of the new German democratic state and society and saw the need for families to rear children for the future of the nation. It was considered to be the source of morality, stability, well-being, and culture and the central base of the nation.

In the early years of the Weimar Republic, these claims found a majority within the Reichstag and the BDF (among others), but already in the second half of the 1920s, supporters of divorce reform could not reiterate their claims as conservative women's organizations became too powerful within the BDF. In addition, many women did not understand the full reform proposal and that all parts of the family law reform claims were interrelated with each other in order to protect women after divorce. As the basic agreement on divorce reform was waning, the BDF board replaced it strategically to stress and discuss the need for the reform of married women's property rights. The reorganization of matrimonial property law appealed to all women because the community of gains, as suggested by the female lawyers, had both conservative and progressive elements. Conservative women saw that the model of the family as an institution was strengthened and that gender separations work were preserved. However, it was radical at the same time because it was not only the work of the man

internationaler Perspektive im 19. und 20. Jahrhundert, eds. Vincent Streichhahn and Frank Jacob (Berlin: Metropol, 2020), 154-181.

44 Verhandlungen des Reichstags, session November 20, 1928, vol. 423 (Berlin: Druck und Verlag der Reichsdruckerei, 1929), 564-569. 
within the family that had an economic impact but also that of the woman. So, this proposal found encouragement, both within the politically diverse women's movement as well as in parliament, from more groups than for the ideas for reforming divorce and the consequences of divorce. In fact, the Center Party agreed with former statements about a new order of the marital property law in order to prevent the divorce reform. ${ }^{45}$

The reform opposers, the Center Party and its political allies, the German National People's Party (Deutschnationale Volkspartei, DNVP) and the German People's Party (Deutsche Volkspartei, DVP), strongly objected to the proposed reforms and vigorously defended their proposed hold over marriage. According to them, the reforms, especially those relating to divorce, would taint the sacred bond of marriage and would lead to men freeing themselves from their older wives and marrying younger brides. Thus, emancipation and equality in family law would bring only suffering to married women instead of the claimed freedom. For them, the reform would lead to a weakening of the family as a social institution and thus to a weakening of the state, causing great harm to the fragile post-war German nation. They were also afraid that the possible breakup of families would lead to a further reduction of children born to a country that had lost millions in the war. ${ }^{46}$

In addition, these parties invoked the dangers of Bolshevism as a reason to stall reform. In Russia, the no-fault divorce was introduced besides broader family law reforms, and the supposed breakdown of the Russian state was used as a warning to all the reform claimants in the Reichstag, especially the Social Democrats and the Communists. While the Communists openly supported implementing the Russian ideas in Germany, the SPD often did not push its ideas strongly enough in order to keep the peace with its coalition partners, which

45 BDF Ausschuss für Ehegüterrecht, Landesarchiv Berlin (henceforth LAB B), Rep. 235-01 BDF, MF-Nr. 2126; Bormann, "Gleichstellung," 1036-1046; Emmy Rebstein-Metzger, "Gütertrennung oder Gütergemeinschaft?” Die Frau 34, no. 10 (1927): 522-527; Marie Munk, “Inwiefern bedürfen die familienrechtlichen Vorschriften des BGB mit Rücksicht auf den die Gleichberechtigung aussprechenden Art. 119 Abs. 1 Satz 2 RV einer Änderung?” Deutsche Richterzeitung 23, no. 8/9 (1931): 300 -303; Camilla Jellinek, "Vom Jammer des ehelichen Güterrechts," Die Frau 34, no. 7 (1927): 409-417; Marion Röwekamp, "Misjudged and Underestimated: The Family Law Claims of the Bund Deutscher Frauenvereine on Matrimonial Property Law, 1918-1933,” in Gender Difference in European Legal Cultures: Historical Perspectives. Dedicated to Heide Wunder on the Occasion of her 70th Birthday, ed. Karin Gottschalk (Stuttgart: Franz Steiner Verlag, 2013), 221-234.

46 See, for example, Schubert, Projekte, 542-544, Deutsche Volkspartei, ed., Stichworte für den Wahlkampf 1930 (Berlin: Staatspolitischer Verlag, 1930), 621-628. 
cost them lots of votes, especially from women, who turned away from the party. ${ }^{47}$

Despite all these disagreements, by 1928, most parties understood that some kind of reform to the family law was unavoidable and were tired of the debates; even the DVP supported reform movements, such as divorce after five years of separation on the grounds of irretrievable breakdown and the end of the principle of guilt. The DNVP and the Protestant women's movement, while thinking that some reform was needed, stressed the principle of guilt and that divorce, especially based on the claim of one party, would create a problem for elderly wives. The Catholic Church, the Center Party, as well as the Catholic women's movement stood strong in their understanding of marriage as a sacrament that could not be dissolved. They went so far as to leave a debate in the Reichstag in 1929 because the Chancellor refused to postpone the debates once again based on the Center Party's protest. As Dirk Blasius has pointed out, they were willing to put the government at risk in order to hold their ground on the question of divorce law. ${ }^{48}$

The other areas of family law, such as the reform proposals for personal marriage law, married women's property law, custody law, and the law regarding illegitimate children, suffered the same fate, even though, in the latter case, all parties agreed that the fate of these children had to be approved. The parties of the left and the women's movement asked for a reform of the civil law and claimed, based on Art. 121 of the constitution, that illegitimate children should receive the same legal position as legitimate children in terms of inheritance, alimony, and education. ${ }^{49}$ The death rate of illegitimate children in the first years of

47 "Ehebolschewismus," Schlesische Tagespost, March 7, 1928; DNVP MP Freytagh-Loringhoven on "Ehebolschewismus," in Schubert, Projekte, 566-567; Deutsche Volkspartei, Stichworte, 64. For a positive view about the SU family law: MP Arendsee, 22. session, November 30, 1928, 578; however parts of the SPD were critical: Hedwig Schwarz, "Beruf und Mutterschaft," Die Genossin 5 (1928): 440. See also Heinemann, Zwischen Familie und Emanzipation, 99 and 145-149; Atina Grossmann, "German Communism and New Women: Dilemmas and Contradictions," in Women and Socialism: Socialism and Women, eds. Helmut Gruber and Pamela Graves (New York/Oxford: Berghahn, 1998), 135-168; Björn Laser, Kulturbolschewismus! Zur Diskursemantik der "totalen Krise" 1929-1933 (Frankfurt/Main: Peter Lang, 2010).

48 Blasius, Ehescheidung in Deutschland, 182-187.

49 Marie Munk, Das Recht der Unehelichen, LAB B Rep. 235-01 BDF MF-Nr. 2765; Marie Munk, “Die künftige Regelung der Rechte des unehelichen Kindes,” Die Frau 33, no. 3 (1925): 150 -156; Marie Munk, "Der Gesetzesentwurf ueber die unehlichen Kinder und die Annahme an Kindes Statt,” Deutsche Juristen Zeitung 31, no. 15 (1926): 1069-1074; Gertrud Bäumer, "Der Unehelichenschutz und die legitime Familie," Die Frau 36, no. 6 (1929): 336-341; Elsbeth Georgi, "Zur Reform des Unehelichenrechts," Die Frau 36, no. 10 (1929): 621-625; Hilde Eiserhardt, "Das Unehelichenrecht im Reichstag," Soziale Praxis und Archiv für Volkswohlfahrt 38, no. 9 
their life was in fact double that of legitimate ones in 1919. But the conservative parties thought the civil law was not the right tool to improve their fate but would only endanger and destroy the traditional family and further weaken the morals of women. They suggested solving the problem through social law, and in fact the Reich Youth Welfare Law of July 1922 did give some relief to the situation of illegitimate children. The newly introduced juvenile offices and their guardians oversaw the wellbeing of the kids and that the fathers would pay child support. ${ }^{50}$ In civil law, the draft for the equal treatment of illegitimate and legitimate children published by the government in 1925 found more common ground than the one on divorce law. People could get involved in it since the previous gender division of labor in the family and the marriage as a fundamental principle of life were not questioned here. But the Center Party again did not like the idea that it would morally encourage the wrong form of families. So the draft law again did not become law.

\section{Conclusion}

The debates over family law reform and especially over divorce reform illustrate the conflict that surrounded marriage and family as a social institution. In between all these ideologies around the marriage and family on the one hand as well as around socialism and Catholicism on the other, the reform of divorce law while keeping the family model intact was an impossible task. This became obvious in the debates in the Reichstag, in the legal science, and in the media, but also in the women's movement itself. No wonder that every suggested change to family law touched the nerves of the entire society. The family law claims of the reform proponents such as the Social Democrats communists, and the women's movement, for example, were bedded into a more complex picture than a simple law reform. The question was central to the task to redefine the new state and to modify the "traditional" family to maintain their function in society on the one hand but also to fit into the new democracy on the other. The equality of women in the family constantly clashed with the role of

(1929): 219-222, 288 -291; Hans Maier, "Die Sozialdemokratie und das Gesetz über die unehelichen Kinder,” Die Genossin 6 (1929): 11-16; Hanna Scherpner-Drexel, Rechte unehelicher Kinder aus den Sozialgesetzen (Stand vom 1. Januar 1926) (Langensalza: H. Beyer, 1926). See also: Schubert, Projekte, 29-81; Sybille Buske, Fräulein Mutter und ihr Bastard: Eine Geschichte der Unehelichkeit in Deutschland 1900-1970 (Göttingen: Wallstein, 2004), 82-85; Heinemann, Familie zwischen Tradition und Emanzipation, 181-205.

50 Buske, Fräulein Mutter, 109-114. 
the family in the functioning of the state. Even supporters of family law reform often did not believe in the right of women to full equality; they also believed in the fact that men and women held different roles and duties in the family (and the state) to which they were suited by nature. To fully quit the male breadwinner model was not within the mental range even of the major part of the women's movement, even less the rest of the society.

Women's main demand for political equality was fulfilled with the right to vote, and their right to vote became to some extent a symbol of the new, democratic Germany. The granting of women's suffrage was, however, only a first step toward the attainment of full citizenship rights for women, and the declaration of equality in the constitution was just that: a declaration, not a realization. The Weimar Constitution had introduced democracy just as little as equal rights for women; it was a steady process of negotiation toward realizing these goals. Analyzing this process shows us the understanding of all involved parties and what democracy meant to them, which principles of the constitution were important to them and which were not. Women's equality was introduced in the constitution, it offered a blueprint for beginning a democratization process, but the constitution was not the end product the women had hoped for to guarantee equal rights just by formulating them. The weak draft of the constitution already provided for the fact that women had to keep on fighting for every further step toward equal rights beyond the right to vote, namely civil, social and economic equality. All concrete efforts by women and the parties of the left to achieve equality in family law were a process of negotiation to determine to what extent the young democracy was now willing to implement the constitutionally guaranteed rights for women. As we have seen, these claims reached the limit of negotiability sooner than the women had hoped according to the limits the constitution provided for. The demands to bring democracy into marriage and the family reached a clear and inflexible negotiating limit.

However, the debates on equal rights for women show that there was at least room for these debates, although they rarely ended in favor of women. Above all, they had the right and repeatedly demanded the place for the debates. These debates were characterized by a generally very slow change to understanding women's role in society. Women were somehow considered to be equal but at the same time different, the difference being caused by the different "nature" of the sexes. This understanding and the fear of social disintegration, especially of the family and, in the second step, of the nation, shaped the debates on women's citizenship rights in society and within all parties. For it was precisely the rights demanded for women and the expression that the changed roles of women in the form of the "new women" found so obvious were interpreted as symbolizing that the nation was in moral disintegration. Besides, the number 
of women calling for change was a small group of elite women. For most of the other women, the choices the new family law might provide seemed risky as they primarily wanted to be homemakers. To be a full-time housewife was generally the ideal that not only all middle-class women but even socialist women dreamed of. The latter, being burdened by economic hardships or the double burden of paid work and the family's needs at home (and without the domestic help of the middle-class professional and stay-at-home women), understandably found the idea very attractive. And women who were full-time housewives did not want to lose the security the law provided for them as they understood it. For them, the divorce claims in particular seemed to threaten the basis of their existence. They rather saw themselves as protected by a law that disempowered them while at the same time not understanding the full mechanism of protection the reform claims provided. They wanted reforms that would strengthen their rights within an existing family, to force husbands to be responsible for the family and themselves. They wanted domestic work to be recognized as essential and important as paid work. They wanted women's power within the family, not outside the family, to be increased. And if the belief in God and the holy union came into the picture, the different roles within the family, even in the minds of reformists, and society were not only provided by nature but also by God. But of course, in the minds of reformists, divorce was a devastating concept for women as, in their view, marriage was the ideal way for women to live. So, women themselves were too ambivalent about the idea of equality in the family and in the state to push together with one idea for women's full citizenship rights. Women in general wanted more social justice and security within the new state rather than individual freedoms or full equality, and most men could live with this concept. Claims beyond these needs that maybe coincidentally also served the needs of the German nation were more difficult to negotiate.

When men were recognized as citizens by the state, they automatically filled in their new rights because they already had power within the family and because their general ability to fill the concept of them as individuals with full legal capacity was never really questioned. When women gained citizenship (in principle) in 1918, they still faced the fact that they were not full legal persons in the family and were, in general, limited to the domestic sphere. To overcome these barriers was not only a question of the law but also of overcoming mental structures and finding a new, growing consensus of women and men about women's new role in family, society, and the state. We can see how difficult this proved to be as we are still in the middle of this process. 


\section{Works Cited}

\section{Archival Material}

\section{Archiv der deutschen Frauenbewegung (ADF)}

NL-K-08 Deutscher Staatsbürgerinnenverband, Nachlass Louise Otto-Peters, 3;

\section{Landesarchiv Berlin}

LAB B Rep. 235-01 BDF, MF-Nr. 2126.

LAP B Rep. 235-01 BDF, MF-Nr. 2765.

\section{Published Sources and Secondary Works}

Aldag, Heinrich. Die Gleichheit vor dem Gesetz in der Reichsverfassung: Eine öffentlichrechtliche Abhandlung auf rechtsvergleichender Grundlage. Berlin: Heymann, 1925.

Ankum, Katharina von, ed. Women in the Metropolis: Gender and Modernity in Weimar Culture. Berkeley: University of California Press, 1997.

Augspurg, Anita. “Gebt acht, solange noch Zeit ist!” Die Frauenbewegung 1, no. 1 (1895): $4-5$.

Barber Crosby, Margaret. "The Civil Code and The Transformation of German Society: The Politics of Gender Inequality, 1814-1919.” PhD diss., Brown University, 2001.

Bäumer, Gertrud. “Der Unehelichenschutz und die legitime Familie.” Die Frau 36, no. 6 (1929): 336-341.

Berneike, Christiane. Die Frauenfrage ist Rechtsfrage: Die Juristinnen der deutschen Frauenbewegung und das Bürgerliche Gesetzbuch. Baden-Baden: Nomos, 1995.

Beschwitz, Olga von. Begleitschrift zu der Petition des Bundes Deutscher Frauenvereine an den Reichstag betr. das Familienrecht des neuen BGB für das Deutsche Reich. Frankenberg: L. Reisel, 1899.

Blasius, Dirk. Ehescheidung in Deutschland (1794-1945). Göttingen: Vandenhoeck \& Ruprecht 1987.

Boak, Helen. Women in the Weimar Republic. Manchester: Manchester University Press, 2015.

Bock, Gisela. "Frauenwahlrecht. Deutschland um 1900 in vergleichender Perspektive." In Geschichte und Emanzipation: Festschrift für Reinhard Rürup, edited by Michael Grüttner, Rüdiger Hachtmann and Heinz-Gerhard Haupt, 95-136. Frankfurt am Main/New York: Campus: 1999.

Bormann, Ella. “Die Gleichstellung der Geschlechter im deutschen Eherecht.” Sozialistische Monatshefte 27, no. 19 (1921): 1036-1045.

Buske, Sybille. Fräulein Mutter und ihr Bastard: Eine Geschichte der Unehelichkeit in Deutschland 1900-1970. Göttingen: Wallstein, 2004. 
Deutsche Volkspartei, ed. Stichworte für den Wahlkampf 1930. Berlin: Staatspolitischer Verlag, 1930.

Dittmar, Louise. "Das Wesen der Ehe." In Das Wesen der Ehe nebst einigen Aufsätzen über die soziale Reform der Frauen, edited by Louise Dittmar, 47-62. Leipzig: Verlag von Otto Wiegand, 1849.

Dittmar, Louise. "Die männliche Bevormundung." In Das Wesen der Ehe nebst einigen Aufsätzen über die soziale Reform der Frauen, edited by Louise Dittmar, 62-64. Leipzig: Verlag von Otto Wiegand, 1849.

Dohm, Hedwig. Der Frauen Natur und Recht. Berlin: Wedekind \& Schwieger, 1876.

Dölemeyer, Barbara. "Frau und Familie im Privatrecht des 19. Jahrhunderts." In Frauen in der Geschichte des Rechts: Von der frühen Neuzeit bis zur Gegenwart, edited by Ute Gerhard, 633-658. Munich: C.H. Beck, 1997.

Dölle, Gilla, ed. Eine "ächt weibliche Emancipation": Die Diskussion der Geschlechterbeziehungen um 1848. Kassel: Archiv der deutschen Frauenbewegung, 1998.

Dose, Cäcilie and Alma Kriesche. Die Stellung der Frau und Mutter im Familienrecht der ausserdeutschen Staaten und nach den Bestimmungen des neuen bürgerlichen Gesetzbuches für das Deutsche Reich. Frankenberg: L. Reisel, 1900.

"Ehebolschewismus." Schlesische Tagespost, March 7, 1928.

Eiserhardt, Hilde. "Das Unehelichenrecht im Reichstag." Soziale Praxis und Archiv für Volkswohlfahrt 38, no. 9 (1929): 219-222, 288-291.

Evans, Ellen Lovell. The German Center Party, 1870-1933: A Study in Political Catholicism. Carbondale: Southern Illinois University Press, 1981.

Fels, Orla-Maria. "Die Deutsche Bürgerliche Frauenbewegung als juristisches Phänomen." PhD diss., Freiburg University, 1959.

Freund, Marion. “Mag der Thron in Flammen glühn!" Schriftstellerinnen und die Revolution 1848/49. Königstein/Taunus: Helmer, 2004.

Geisel, Beatrix. Klasse, Geschlecht und Recht: Vergleichende sozialhistorische Untersuchung der Rechtsberatungspraxis von Frauen- und Arbeiterbewegung (1894-1933). Baden-Baden: Nomos, 1997.

Georgi, Elsbeth. "Zur Reform des Unehelichenrechts." Die Frau 36, no. 10 (1929): 621-625.

Gerhard, Ute. "Legal Particularism and the Complexity of Women's Rights in Nineteenth Century Germany." In Private Law and Social Inequality in the Industrial Age: Comparing Legal Cultures in Britain, France, Germany, and the United States, edited by Willibald Steinmetz, 137-154. Oxford: Oxford University Press, 2000.

Gerhard, Ute. Gleichheit ohne Angleichung: Frauen im Recht. Munich: C.H. Beck, 1990.

Gierke, Otto von. Der Entwurf eines bourgeoisen Gesetzbuchs und das deutsche Recht. Leipzig: Dunker \& Humblot, 1899.

Gross, Michael B. The War Against Catholicism: Liberalism and the Anti-Catholic Imagination. Ann Arbor: University of Michigan, 2004.

Grossman, Atina. Reforming Sex: The German Movement for Birth Control and Abortion Reform 1920-1950. New York: Oxford University Press, 1995.

Grossmann, Atina. "German Communism and New Women: Dilemmas and Contradictions." In Women and Socialism: Socialism and Women, edited by Helmut Gruber and Pamela Graves, 135-168. New York/Oxford: Berghahn, 1998. 
Hachenburg, Max. "Interfraktioneller Antrag der weiblichen Reichstagsabgeordneten auf Zulassung von Frauen zu den juristischen Prüfungen.” Deutsche Juristen Zeitung 26 (1921): 174.

Hagemann, Karen. Frauenalltag und Männerpolitik: Alltagsleben und gesellschaftliches Handeln von Arbeiterfrauen in der Weimarer Republik. Bonn: Dietz, 1990.

Hausen, Karin. "Arbeiterinnenschutz, Mutterschutz und gesetzliche Krankenversicherung im Deutschen Kaiserreich und in der Weimarer Republik: Zur Funktion von Arbeits- und Sozialrecht für die Normierung und Stabilisierung der Geschlechterverhältnisse." In Frauen in der Geschichte des Rechts: Von der frühen Neuzeit bis zur Gegenwart, edited by Ute Gerhard, 759-771. Munich: C.H. Beck, 1997.

Heinemann, Rebecca. Familie zwischen Tradition und Emanzipation: Katholische und sozialdemokratische Familienkonzeptionen in der Weimarer Republik. Munich: Oldenbourg 2004),

Hong, Young-Sun. Welfare, Modernity, and the Weimar State. Princeton, NY: Princeton University Press, 1998.

Hönig, Klaus. Der Bund Deutscher Frauenvereine in der Weimarer Republik 1919-1933. Frankfurt am Main: Hänsel-Höhenhausen, 1995.

Humphrey, Michael. Die Weimarer Reformdiskussion über das Ehescheidungsrecht und das Zerrüttungsprinzip: Eine Untersuchung über die Entwicklung des Ehescheidungsrechts in Deutschland von der Reformation bis zur Gegenwart unter Berücksichtigung rechtsvergleichender Aspekte. Göttingen: Cuvellier, 2006.

Jellinek, Camilla. “Vom Jammer des ehelichen Güterrechts.” Die Frau 34, no. 7 (1927): 409-417.

Joos, Joseph. Die sozialdemokratische Frauenbewegung in Deutschland. Mönchen-Gladbach: Volksvereins-Verlag 1912.

Kimble, Sara and Marion Röwekamp. "Legal Cultures and Communities of Female Protest in Modern European History, 1860-1960s.” In New Perspectives on European Women's Legal History, edited by Sara Kimble and Marion Röwekamp, 1-24. New York: Routledge, 2017.

Klemm, Sabine. Frauenbewegung und Familienrecht 1848 bis 1933: Eine Betrachtung anhand von Quellen. Tübingen: Campus, 1999.

Kundrus, Birthe. Familienpolitik und Geschlechterverhältnisse im Ersten und Zweiten Weltkrieg. Hamburg: Christians, 1995.

Lange, Helene. “Über das Frauenwahlrecht.” Neue Bahnen 33, no. 7 (1898): 68-69.

Laser, Björn. Kulturbolschewismus! Zur Diskursemantik der "totalen Krise” 1929-1933. Frankfurt/Main: Peter Lang, 2010.

Lauterer, Heide-Marie. Parliamentarierinnen in Deutschland 1918/19-1949. Königstein, Taunus: Ulrike Helmer, 2002.

Lion, Hilde. Zur Soziologie der Frauenbewegung: Die sozialistische und die katholische Frauenbewegung. Berlin: Herbig, 1926.

Lüders, Marie-Elisabeth. "Interfraktionelle Frauenarbeit.” Die Frau 27, no. 5 (1920): 154-156.

Lüders, Marie-Elisabeth. "Vorschläge zum Ehescheidungsrecht.” Die Frau 35 (1928): 325-331.

Maier, Hans. "Die Sozialdemokratie und das Gesetz über die unehelichen Kinder." Die Genossin 6 (1929): 11-16.

Meder, Stephan and Christoph-Eric Mecke, eds. Reformforderungen zum Familienrecht International, vol. 1: Westeuropa und die USA (1830-1914). Cologne: Böhlau 2015. 
Meder, Stephan, Arne Duncker, and Andrea Czelk, eds. Frauenrecht und Rechtsgeschichte: Die Rechtskämpfe der deutschen Frauenbewegung. Cologne: Böhlau, 2006.

Meder, Stephan, Arne Duncker, and Andrea Czelk, eds. Die Rechtsstellung der Frau um 1900: Eine kommentierte Quellensammlung. Cologne: Böhlau, 2010.

Mikus, Birgit. The Political Woman in Print: German Women's Writing 1845-1919. Oxford et al: Peter Lang, 2014.

Möhrmann, Renate. Die andere Frau: Emanzipationsansätze deutscher Schriftstellerinnen im Vorfeld der Achtundvierziger-Revolution. Stuttgart: Metzler, 1977.

Möhrmann, Renate, ed. Frauenemanzipation im deutschen Vormärz: Texte und Dokumente. Stuttgart: Reclam, 1980.

Mouton, Michelle. From Nurturing the Nation to Purifying the Volk: Weimar and Nazi Family Policy, 1918-1945. Cambridge/New York: Cambridge University Press, 2007.

Mugdan, Benno. Die gesammten Materialien zum Bürgerlichen Gesetzbuch für das Deutsche Reich, vol. 4. Berlin: G. Schenck, 1899.

Munk, Marie. "Der Gesetzesentwurf ueber die unehlichen Kinder und die Annahme an Kindes Statt.” Deutsche Juristen Zeitung 31, no. 15 (1926): 1069-1074.

Munk, Marie. "Die künftige Regelung der Rechte des unehelichen Kindes." Die Frau 33, no. 3 (1925): 150-156.

Munk, Marie. "Inwiefern bedürfen die familienrechtlichen Vorschriften des BGB mit Rücksicht auf den die Gleichberechtigung aussprechenden Art. 119 Abs. 1 Satz 2 RV einer Änderung?" Deutsche Richterzeitung 23, no. 8/9 (1931): 300-303.

Munk, Marie. Vorschläge zur Umgestaltung des Rechts auf Ehescheidung und der elterlichen Gewalt nebst Gesetzesentwurf. Berlin: Herbig, 1923.

Niggemann, Heinz. Emanzipation zwischen Sozialismus und Feminismus: Die sozialdemokratische Frauenbewegung im Kaiserreich. Wuppertal: Hammer, 1981.

Offen, Karen. "National or International? How and Why the Napoleonic Code Drove Married Women's Legal Rights onto the Agenda of the International Council of Women and the League of Nations: An Overview." In Family Law in Early Women's Rights Debates, edited by Stephan Meder and Christoph-Eric Mecke, 42-59. Cologne: Böhlau, 2013.

"Petition of the Allgemeinen Deutschen Frauenverein to the Reichstag." Neue Bahnen 12, no. 8 (1877): 57-59.

Pfülf, Antonie. "Die Auflösung der alten Familie." In Jugendnot, edited by Gerhard Danziger et al., 26-30. Leipzig: Oldenburg, 1922.

Pfülf, Antonie. "Die Reform des Ehescheidungsrechts." Arbeiterwohlfahrt 3 (1928): 3-9.

Plat, Wolfgang. "Die Stellung der deutschen Sozialdemokratie zum Grundsatz der Gleichberechtigung der Frau auf dem Gebiet des Familienrechts bei der Schaffung des Bürgerlichen Gesetzbuches des Deutschen Reiches." PhD diss., Humboldt University Berlin, 1966.

Rebstein-Metzger, Emmy. “Gütertrennung oder Gütergemeinschaft?” Die Frau 34, no. 10 (1927): 522-527.

Rebstein-Metzger, Emmy. "Scheidung schuldlos zerrütteter Ehen.” Deutsche Juristen Zeitung 32, no. 10 (1927): 715-719.

Riedel, Tanja-Carina. Gleiches Recht für Mann und Frau: Die bürgerliche Frauenbewegung und die Entstehung des BGB. Cologne: Böhlau, 2008.

Riehl, Wilhelm Heinrich. Die Naturgeschichte des Volkes als Grundlage einer deutschen Social-Politik: Die Familie, vol. 3. Stuttgart/Augsburg: Cotta, 1855. 
Röhl, Elisabeth. “Ehereform.” Die Gleichheit 29, no. 14 (1919): 109-111.

Rosenbusch, Ute. Der Weg zum Frauenwahlrecht in Deutschland. Baden-Baden: Nomos, 1998.

Rost, Ida. Die Ehescheidungen der Jahre 1920-1924 von in Sachsen geschlossenen Ehen, unter besonderer Berücksichtigung der Dauer der Ehen und des Heiratsalters der geschiedenen Ehegatten. Leipzig: Vieweg \& Teubner Verlag, 1927.

Röwekamp, Marion. “'Männer und Frauen haben grundsätzlich die gleichen staatsbürgerlichen Rechte': Weimar - Meilenstein auf dem Weg zur Gleichberechtigung der Geschlechter?" In Die Weimarer Verfassung, Wert und Wirkung für die Demokratie, edited by Friedrich-Ebert-Stiftung, 235-164. Erfurt: Friedrich-Ebert-Stiftung, 2009.

Röwekamp, Marion. "Der Kampf um die Ehe: Der Katholischer Frauenbund und das Zentrum im Richtungsstreit um eine Reform des Ehescheidungsrechts." In Die Frauen und der politische Katholizismus, edited by Markus Raasch and Andreas Linsenmann, 210 - 237. Mainz: Schöningh, 2018.

Röwekamp, Marion. "Gedachte Grenzen. Ehescheidungsrechtsforderungen als Grenze innerhalb der Bürgerlichen Frauenbewegung, 1918-1933.” Ariadne 57 (2010): 14-21.

Röwekamp, Marion. "Margarete Berent und Marie Munk: Pionierinnen im Kampf um gleiche Rechte für Frauen.” In Streitbare JuristInnen: Eine andere Tradition, vol. 2, edited by Tanja Hitzel-Cassangnes and Joachim Perels, 73-108. Baden-Baden: Nomos, 2015.

Röwekamp, Marion. Marie Munk: Rechtsanwältin - Richterin - Rechtsreformerin. Berlin: Hentrich \& Hentrich, 2014.

Röwekamp, Marion. "Misjudged and Underestimated: The Family Law Claims of the Bund Deutscher Frauenvereine on Matrimonial Property Law, 1918-1933." In Gender Difference in European Legal Cultures: Historical Perspectives. Dedicated to Heide Wunder on the Occasion of her 70th Birthday, edited by Karin Gottschalk, 221-234. Stuttgart: Franz Steiner Verlag, 2013.

Röwekamp, Marion. "Olympe de Gouges, Louise Otto-Peters und der Kampf um das Familienrecht in Frankreich und Deutschland." In Die Rechte der Frauen 1791-1866-2016, edited by Sandra Berndt and Gerlinde Kämmerer, 21-43. Markkleeberg: Sax-Verlag Beucha, 2017.

Röwekamp, Marion. "Reform Claims in Family Law and Legal Struggles within the International Council of Women, 1888-191." In Forging Bonds Across Borders: Transatlantic Collaborations for Women's Rights and Social Justice in the Long Nineteenth Century, edited by Anja Schüler and Britta Waldschmidt-Nelson, 75-93. Washington, DC: Bulletin of the German Historical Institute, Supplement 13, 2017.

Röwekamp, Marion. "The double bind. Von den Interdependenzen des Frauenwahlrechts und des Familienrechts vor und nach 1918." In 100 Jahre Frauenwahlrecht: Kampf, Kontext, Wirkung, edited by Hedwig Richter and Kerstin Wolff, 99-121. Hamburg: Verlag des Hamburger Instituts für Sozialforschung, 2018.

Röwekamp, Marion. "Von der Klassenkämpferin zur Republikanerin. Sozialdemokratinnen in der Weimarer Republik." In Geschlecht und Klassenkampf: Die "Frauenfrage" aus deutscher und internationaler Perspektive im 19. und 20. Jahrhundert, edited by Vincent Streichhahn and Frank Jacob, 154-181. Berlin: Metropol, 2020.

Scherpner-Drexel, Hanna. Rechte unehelicher Kinder aus den Sozialgesetzen (Stand vom 1. Januar 1926). Langensalza: H. Beyer, 1926. 
Schmidt, Auguste and Goldschmidt, Henriette. Petition und Begleitschrift betreffend das "Familienrecht" in dem Entwurf des neuen bürgerlichen Gesetzbuches für das Deutsche Reich. Leipzig: Schäfer, 1896.

Schöfer, Sophie. "Notwendige Aenderungen der ehelichen Rechtsgrundlagen." Die Neue Zeit 40, no. $1 / 10$ (1921): $230-234$.

Schötz, Susanne. “'Einige Deutsche Gesetzes-Paragraphen' - Louise Otto-Peters und das Engagement des Allgemeinen Deutschen Frauenvereins für Frauenrechte." In Menschenrechte sind auch Frauenrechte, edited by Ilse Nagelschmidt, Susanne Schötz, Nicole Kühnert and Melani Schröter, 53-78. Leipzig: Leipziger Universitätsverlag, 2002.

Schröder, Hannelore. Die Rechtlosigkeit der Frau im Rechtsstaat: Dargestellt am Allgemeinen Preußischen Landrecht, am Bürgerlichen Gesetzbuch und an J.G. Fichtes Grundlage des Naturrechts. Frankfurt am Main/New York: Campus, 1979.

Schubert, Werner. Die Projekte der Weimarer Republik zur Reform des Nichtehelichen-, des Adoptions- und des Ehescheidungsrecht. Munich/Vienna/Zurich: Ferdinand Schöningh, 1986.

Schwab, Dieter. "Gleichberechtigung und Familienrecht im 20. Jahrhundert.” In Frauen in der Geschichte des Rechts: Von der Frühen Neuzeit bis zur Gegenwart, edited by Ute Gerhard, 790-827. Munich: C.H. Beck, 1997.

Schwanecke, Inge. Die Gleichberechtigung der Frau unter der Weimarer Reichsverfassung. PhD diss., University of Heidelberg, 1977.

Sneeringer, Julia. Winning Women's Votes: Propaganda and Politics in Weimar Germany. Chapel Hill: University of North Carolina Press, 2002.

Stritt, Marie. "Die Ehefrau und das bürgerliche Gesetzbuch." In Die Rechtsstellung der Frau im 1900: Eine kommentierte Quellensammlung, edited by Stephan Meder, Arne Duncker and Andrea Czelk, 811-820. Cologne: Böhlau, 2010.

Stritt, Marie. "Germany. Victory for Woman Suffrage." International Women's News 13, no. 4 (1919): $44-48$.

Stritt, Marie. Frauen-Landsturm: Flugblatt zum Familienrecht im bürgerlichen Gesetzbuch. Berlin: n.p., 1896. Reprinted in Die Rechtsstellung der Frau im 1900: Eine kommentierte Quellensammlung, edited by Stephan Meder, Arne Duncker and Andrea Czelk, 805-811. Cologne: Böhlau, 2010.

Szymanski, Hanna. Theorie und Lebenswirklichkeit: Ehe und Eherechte im Spiegel sozialdemokratischer Forderungen im deutschen Kaiserreich. Cologne: Böhlau, 2013.

Usborne, Cornelie. The Politics of the Body in Weimar Germany: Women's Reproductive Rights and Duties. Ann Arbor: University of Michigan Press, 1992.

Verhandlungen der verfassunggebenden Deutschen Nationalversammlung, vol. 328. Stenographische Berichte. Von der 53. Sitzung am 10. Juli 1919 bis zur 70. Sitzung am 30. Juli 1919. Berlin: Norddeutsche Buchdruckerei, 1920.

Verhandlungen des Reichstags. IV. Wahlperiode 1928, vol. 423. Von der 1. Sitzung am 13. Juni 1928 bis zur 40. Sitzung am 4. Februar 1929. Berlin: Druck und Verlag der Reichsdruckerei, 1929.

Vogel, Ursula. “Is Citizenship Gender-Specific?" In The Frontiers of Citizenship, edited by Ursula Vogel and Michael Moran, 58-85. New York: St. Martin's Press, 1991.

Vollmer-Heitmann, Hanna. Wir sind von Kopf bis Fuß auf Liebe eingestellt: Die zwanziger Jahre. Hamburg: Kabel, 1993. 
Weber, Marianne. Ehefrau und Mutter in der Rechtsentwicklung: Eine Einführung. Tübingen:

J. C. B. Mohr, 1907.

Weber-Will, Susanne. Die rechtliche Stellung der Frau im Privatrecht des Preußischen Allgemeinen Landrechts von 1794. Frankfurt am Main/New York: Lang, 1983.

Wieruszowski, Alfred. "Artikel 119: Ehe, Familie, Mutterschaft." In Die Grundrechte und Grundpflichten der Reichsverfassung, vol. 2: Artikel 118-142, edited by Hans Carl Nipperdey, 72-94. Berlin: Hobbing, 1930. 